\title{
Profiling in employment relations and public policies - an instrument of economic risk reduction?*
}

\section{Profilowanie w stosunkach pracy i politykach publicznych - instrumentem obniżania ryzyka gospodarczego?}

\author{
dr Barbara Godlewska-Bujok \\ University of Warsaw, Faculty of Management \\ ORCID: 0000-0002-1167-0515 \\ e-mail: bgodlewska@wz.uw.edu.pl
}

\begin{abstract}
Summary During the public debate on the automation of processes related to employment, there is one question on process of profiling. In my opinion, profiling has always been present in the labour law, and - more generally - as a method of organizing information, necessary to take the right decisions at a given time. Profiling is in fact a popular method that has been used for a long time for the reasons of employment relations, although with development of the information revolution and technological possibilities we have noticed the dangers of using this method of achieving any knowledge necessary for functioning in business, which may be considered as exceeding the legal framework. The fact that profiling is an analytical method is beyond doubt, but it is worth considering what is the deeper sense of using this mechanism. In my opinion, both employers and public authorities use the profiling mechanism to reduce the personal risk of undertaken projects, which translates into an assessment of economic efficiency.
\end{abstract}

Keywords: profiling, labour law, employment law, unemployment, economic risk, social risk.

Streszczenie Podczas debaty publicznej na temat automatyzacji procesów związanych z zatrudnieniem pojawia się często pytanie dotyczące procesu profilowania. Autorka wskazuje, że profilowanie zawsze było obecne w prawie pracy $\mathrm{i}$ - bardziej ogólnie — jako metoda organizowania informacji, niezbędna do podejmowania właściwych decyzji w danym czasie. Profilowanie jest w rzeczywistości popularną metodą stosowaną od dawna ze względu na stosunki pracy, chociaż wraz z rozwojem rewolucji informacyjnej i możliwości technologicznych zauważono niebezpieczeństwa związane $\mathrm{z}$ wykorzystaniem tej metody do uzyskania wiedzy niezbędnej do funkcjonowania w biznesie, przekraczającej dozwolone ramy prawne. Pozostaje poza wszelkimi wątpliwościami, że profilowanie jest metodą analityczną, ale warto się zastanowić, jakie jest głębsze znaczenie korzystania z tego mechanizmu. Zdaniem autorki zarówno pracodawcy, jak i władze publiczne wykorzystują mechanizm profilowania w celu zmniejszenia osobistego ryzyka podejmowanych projektów, co przekłada się na ocenę efektywności ekonomicznej.

Słowa kluczowe: profilowanie, prawo pracy, prawo zatrudnienia, bezrobocie, ryzyko gospodarcze, ryzyko socjalne.

JEL: K31

Str. $17-22$

\section{Bibliography}

Alonso, P. Moscoso, S. Salgado, J. F. (2017). Structured behavioral interview as a legal guarantee for ensuring equal employment opportunities for women: A meta-analysis. The European Journal of Psychology Applied to Legal Context, 9(1), 1523, https://doi.org/10.1016/j.ejpal.2016.03.002

Drabek, A. (2014). Profilowanie pomocy dla bezrobotnych jako nowy sposób na walkę z bezrobociem. Gdańsko- Łódzkie Roczniki Prawa Pracyi Prawa Socjalnego, (4). 
Hart, O. Holmstrom, B. (1986). Theory of Contracts. Working Paper, Department of Economy, Massachusetts Institute of Technology, (418).

Łukasiewicz, A. (2016). Profilowanie bezrobotnych - problemy i wyzwania. Kwartalnik Kolegium Ekonomiczno-Społecznego Studia i Prace/Szkoła Główna Handlowa, (1), https://doi.org/10.33119/KKESSiP.2016.1.9

Malisetty, S. Archana, R. V. Kumari, K. V. (2017). Predictive Analytics in HR Management. Indian Journal of Public HealthResearch \& Development, 8(3), https://doi.org/10.5958/0976-5506.2017.00171.1

Reda-Ciszewska, A. (2018). Profilowanie pomocy dla bezrobotnych. Praca i Zabezpieczenie Spoleczne, (3), 28-33.

Saridakis, G. Lai, Y. Cooper, C. L. (2017). Exploring the relationship between HRM and firm performance: A metaanalysis of longitudinal studies. Human Resource Management Review, 27(1), 87-96, https://doi.org/10.1016/j.hrmr.2016.09.005

Sztandar-Sztanderska, K. Zielenska, M. (2018). Changing social citizenship through information technology. Social Work \& Society, 16(2).

Wojdyło-Preisner, M. (2013). Koncepcje profilowania bezrobotnych. Polityka Społeczna,(3). 